\title{
Teacher's in the Global Age: Diverse Roles
}

\author{
Dr. M. Ravi Babu ${ }^{1 *}$
}

\section{ABSTRACT}

Teacher Education has always been an important component of education since time immemorial. This is because all societies in the world have always needed teachers to propagate/transmit their cultures from one generation to another. Teachers need to be seen as creators of knowledge and thinking professionals. A teacher needs to be an information provider, role model, facilitator, assessor, planner, resource and developer. Educated teachers, with wide knowledge, command the respect of fellow teachers and the people in their communities. They need to be empowered to recognise and value what children learn from their home, social and cultural environment and to create opportunities for children to discover, learn and develop. Teacher is a facilitator, is a friend, and is a philosopher. The purpose of teacher education programme should be to develop in each student his general education and personal culture, his ability to teach and educate others, an awareness of the principles which underlines good human relations and a sense of the responsibility to contribute both by teaching and leading as an example to social, cultural and economic progress. The nation building task will be performed under the leadership of a brilliant set of teacher educators and master educators who will prepare the teachers and who in turn will develop the creative abilities of the teeming millions of the country. This paper discusses the diverse role of teacher's in the global age.

Keywords: Teacher Education, Diversity, Educational Programmes.

Today the world is interconnected and interdependent. We are facing the challenges such as climate change, health epidemics, global poverty, global economic recessions and trade imbalances, assaults on human rights, terrorism, political instability, and international conflicts. It is important to recognize the crucial role of education in contributing to building a culture of peace and condemning instances in which education is undermined in order to attack democracy and tolerance. Educating young people to become global citizens will allow them to learn about the interdependence of the world's systems, believe that solutions to global challenges are attainable, and feel morally compelled to confront global injustices and take responsible action to promote a just, peaceful and sustainable world.

\footnotetext{
${ }^{1}$ M.A (Psy), M.Ed., Ph.D, Trained Graduate Teacher, Telangana State Model School, Telangana, India *Responding Author

(C) 2016 I R Babu; licensee IJIP. This is an Open Access Research distributed under the terms of the Creative Commons Attribution License (http://creativecommons.org/licenses/by/2.0), which permits unrestricted use, distribution, and reproduction in any Medium, provided the original work is properly cited.
} 


\section{Teacher's in the Global Age: Diverse Roles}

As a result of quick economic growth, influence of western culture, over mechanization, urbanization and craving for materialistic life there has been a loss of values and of the value system at the individual level and in the society as a whole. History speaks and universally accepted fact that the teachers are unchallenged custodian of the society and embodiment of evolutions and revolutions of the world. The kingpin in the schooling process is the teacher. If the teacher is personally committed to the values and practices them in his/her own life, the students will imbibe the values for which teacher stands. It is for this reason only those teachers who leave deep impact on their students are remembered and also revered. Therefore, if values have to be nurtured in children it would be crucial that their teachers function as role models. The participation of teachers in the formulation and implementation of educational plans can yield rich dividends, especially in institutional planning and programmes of qualitative improvement. Several of the community improvement programmes and school programmes such as improvement of text books, adoption of better methods of teaching and evaluation, intensive utilisation of available facilities, maintaining contact with community, individual guidance to students, inculcation of social and moral values etc do not need much investment in physical or monetary terms. But their success depends essentially upon the competence of the teachers, their sense of dedication and their identification with the interests of the students committed to their care. But unless they make every effort to cultivate these skills and values they shall not be able to participate effectively in educational programmes and to discharge their responsibility to students and the society.

\section{ROLE OF TEACHER}

The key role of teacher is as facilitator and supportive to learning. Teacher is the one who facilitates learners to realise their potentials, articulate their personal and context specific experiences in ways that are acceptable in the wider context of our nation.

$>\quad$ Teacher has to recognise that in learner centered learning situation, curriculum 'evolves' and is not 'pre designed'; teacher is merely 'prepared' for providing possible supports in the process of learning by learners. Every subsequent learning situation cumulatively provides better insight to teacher in discerning learner needs and, creates pool and identifies varied learning supports.

There is no one 'method' that is effective in causing all learners to learn in similar ways. Each teacher has to find one's own 'style' of learning through perceptive practice but recognise the fact that all learners learn in their own ways.

Teacher needs to recognise him or herself as a 'professional' endowed with the necessary knowledge, attitude, competence, commitment, enthusiasm, spirit of seeking new ways and means, capable of reflection, sensitive and perceptive to not only the learners and the institution but also the emergent concerns in the larger social perspective within which one functions. 


\section{Teacher's in the Global Age: Diverse Roles}

Teacher has to recognise that learners in schools no more need teacher as a source of knowledge. The media explosion challenges their minds with the immense learning choices and possibilities.

Teacher must develop an understanding of the nature and dynamics of 'action' comprising education. Such an understanding would not be a cognitive acceptance of things that occur but will prompt attempt to 'do' things, contemplate on 'what works and does not work', and critically analyse the pros and cons of the action, reflection and internalisation.

Terms like teaching and teacher in their earlier meanings need to be altered, if learning has to take the centre stage in Teacher Education. That is, teaching has an underlying tone of 'what a teacher does'. This is suggestive of the learning being an outcome of teaching which is central. Change in visualising teacher, teacher actions and teacher preparedness in a situation whereas learning goes on in learner specific ways, in various levels, speeds and styles but simultaneously, has to be developed.

$>\quad$ It is visualised that providing for learner autonomy will ensure the stage appropriateness of every learning experience. No doubt, the teacher educators need to be oriented to participate in such a learning situation.

The following are the requisites to be present in a good teacher in a Global Age:

1. Physical appearance- A teacher must have a pleasing appearance. Physique and health are very important for a good leader.

2. Vision and foresight- A teacher cannot maintain influence unless he exhibits that he is forward looking. He has to visualize situations and thereby has to frame teaching instructions, plans and logical programmes.

3. Intelligence- A positive bent of mind and mature outlook is very important.

4. Communicative skills- Able to communicate clearly, precisely and effectively.

5. Objective- A fair outlook which is free from bias and which does not reflects his willingness towards a particular individual. He/She should develop his own opinion and should base his judgment on facts and logic.

6. Knowledge of work- Should very precisely know the nature of work.

7. Sense of responsibility- Responsibility and accountability towards an individual's work is very important to bring a sense of influence.

8. Self-confidence and will-power- Confidence in himself is important to earn the confidence of the students.

9. Humanist- Treating the students on humanitarian grounds is essential for building a congenial environment.

10. Empathy- It is an old adage "Stepping into the shoes of others". This is very important because fair judgment and objectivity comes only then. A teacher should understand the problems and complaints of students and should also have a complete view of the needs and aspirations of students. 


\section{TEACHER EDUCATION FOR THE FUTURE}

The need of a generation of teachers aim is to develop learners instead of teaching them, who help their pupils to become independent (learning to learn) and autonomous learners. Teaching should be practical, flexible and child-centered, there is a hope that the next generation of learners will get the support and skills they need in life during their schooling years from their own teachers. Teachers must provide students with motivation and interest for life-long learning and urge them to become, is essential in the education of the future. The responsibility of governments, higher education institutions, and mostly teacher educators both in pre-and inservice education play a major role towards this development.

Diverse Roles of Teacher's in the Global Age: The following 10 roles are a sampling of the many ways teachers can contribute to their schools' success.

\section{Resource Provider}

Teachers help their colleagues by sharing instructional resources. These might include Web sites, instructional materials, readings, or other resources to use with students. They might also share such professional resources as articles, books, lesson or unit plans, and assessment tools.

\section{Instructional Specialist}

An instructional specialist helps colleagues implement effective teaching strategies. This help might include ideas for differentiating instruction or planning lessons in partnership with fellow teachers.

\section{Curriculum Specialist}

Understanding content standards, how various components of the curriculum link together, and how to use the curriculum in planning instruction and assessment is essential to ensuring consistent curriculum implementation throughout a school. Curriculum specialists lead teachers to agree on standards, follow the adopted curriculum, use common pacing charts, and develop shared assessments.

\section{Classroom Supporter}

Classroom supporters work inside classrooms to help teachers implement new ideas, often by demonstrating a lesson, co-teaching, or observing and giving feedback.

\section{Learning Facilitator}

Facilitating professional learning opportunities among staff members is another role for teacher leaders. When teachers learn with and from one another, they can focus on what most directly improves student learning. Their professional learning becomes more relevant, focused on teachers' classroom work, and aligned to fill gaps in student learning. Such communities of learning can break the norms of isolation present in many schools.

\section{Mentor}

Serving as a mentor for novice teachers is a common role for teacher leaders. Mentors serve as role models; accumulate new teachers to a new school; and advise new teachers about instruction, curriculum, procedure, practices, and politics. Being a mentor takes a great deal of 
time and expertise and makes a significant contribution to the development of a new professional.

\section{School Leader}

Being a school leader means serving on a committee, such as a school improvement team; acting as a grade-level or department chair; supporting school initiatives; or representing the school on community or district task forces or committees. A school leader shares the vision of the school, aligns his or her professional goals with those of the school and district, and shares responsibility for the success of the school as a whole.

\section{Data Coach}

Although teachers have access to a great deal of data, they do not often use that data to drive classroom instruction. Teacher leaders can lead conversations that engage their peers in analyzing and using this information to strengthen instruction.

\section{Catalyst for Change}

Teacher leaders can also be catalysts for change, visionaries who are "never content with the status quo but rather always looking for a better way. Teachers who take on the catalyst role feel secure in their own work and have a strong commitment to continual improvement. They pose questions to generate analysis of student learning.

\section{Continuous Learner}

Among the most important roles teacher leaders assume is that of learner. Learners model continual improvement, demonstrate lifelong learning, and use what they learn to help all students achieve.

\section{MULTIPLE ROLES FOR TEACHERS}

Teachers exhibit leadership in multiple, sometimes overlapping, ways. Some leadership roles are formal with designated responsibilities. Other more informal roles emerge as teachers interact with their peers. The variety of roles ensures that teachers can find ways to lead that fit their talents and interests. Regardless of the roles they assume, teacher leaders shape the culture of their schools, improve student learning, and influence practice among their peers

\section{CONCLUSION}

The changes that took place in schools have changed the roles of teachers, too. In the past teachers used to be the major source of knowledge, the leader and educator of their students' school life. Teachers would organize after-school activities. They used to be the authority in the class and often took over the role of parents. Nowadays, teachers provide information and show their students how to tackle them. Although they are still considered to be a kind of leader in the class, they can be thought of as facilitators in the learning process. They are supporters rather than educators and also advisors towards parents. This is high time when Teacher Education programmes should combine knowledge, experiences and dreams pertaining to the building of peace and harmony on one hand, and joint effort of other people and agencies of education on the other to create knowledge and thinking professionals. The nation building task will be 
performed under the leadership of a brilliant set of teacher educators and master educators who will prepare the teachers and who in turn will develop the creative abilities of the teeming millions of the country.

\section{BIBLIOGRAPHY}

Aggarwal J.C (2000), Theory and Principles of Education, $12^{\text {th }}$ Revised Edition, New Delhi: Vikas Publishing House Pvt Ltd.

Gaurav Datt \& Ashwani Mahajan (2012), Indian Economy, 64 ${ }^{\text {th }}$ Revised Edition, New Delhi: S.Chand \& Company Ltd.

NCERT (2005). National Curriculum Framework for School Education, New Delhi: NCERT.

Perraton H., Creed C and Robinson, B. (2002). Teacher Education Guidelines: Using Open and Distance Learning. UNESCO: Paris.

Singh, T D., \& Desmond, M. Tutu. (2005). Towards a Culture of Harmony and Peace. Kolkata: Anderson Printing House Pvt Ltd.

Timpson, William M. (2002). Teaching and Learning Peace. Madison, Wisconsin: Atwood Publishing.

UNESCO (2002), Teacher Education Guidelines: Using Open and Distance Learning Technology, Curriculum, Cost, Evaluation. UNESCO: Paris.

UNESCO (2009), Projecting the Global Demand for Teachers: Meeting the Goal of Universal Primary Education by 2015. UNESCO, Institute for Statistics: Paris.

United Nations (2005). Millennium Development Goals Report 2005. Retrieved October 5, 2007, from: http://unstats.un.org/unsd/mi/pdf/MDG\%20Book.pdf

How to cite this article: R Babu (2016), Teacher's in the Global Age: Diverse Roles, International Journal of Indian Psychology, Volume 3, Issue 3, No. 10, DIP: 18.01.176/20160303, ISBN: 978-1-365-19879-3 